\title{
TURKISH WOMEN'S PREDICAMENT
}

\author{
Meltem MÜFtüLeR-BAC \\ Department of Political Science, Bilkent University, Ankara 06533, Turkey
}

\begin{abstract}
Synopsis - To the foreign observer, Turkish women constitute an anomaly amongst Muslim societies. Since the creation of the Turkish Republic in 1923, Turkey has engaged in a project of modernization and secularization. As part and parcel of this process of modernization, Turkish women have been granted social, political, and legal rights. Despite Kemalist reforms of the 1920s, the basics of male domination stayed intact. It is this paradoxical character of Kemalist reforms that this article emphasises. The legal equality granted to Turkish women did not succeed in their emancipation. The image of Turkey as the only modern, secular, democratic country in the Islamic Middle East has been an effective distortion, concealing many truths about Turkey. The author proposes that the Mediterranean culture, the Islamist traditions, and the Kemalist ideology act together in perpetuating the oppression of women in Turkey and keep patriarchy intact. (C) 1999 Elsevier Science Ltd. All rights reserved.
\end{abstract}

To many students of Turkish society and politics, the status of Turkish women is a puzzle. Turkey is said to be the only modern, democratic, Islamic country, which makes it somewhat an anomaly among the Islamic world, and the status of Turkish women visibly marks this difference. The aim of this article is not so much to focus on the struggle going on over women in Turkey, but rather to look at the underlying social dynamics of this struggle and emphasise the paradoxical character of women's emancipation in Turkey. Since the creation of the modern Turkish Republic (October 29, 1923), the ultimate aim for the modernisers has been to gain acceptance for Turkey among the European system of states (Berkes, 1964; Lewis, 1961; Mardin, 1991). This objective is best summarized by the Turkish Republic's founder, Mustafa Kemal Atatürk, as "our aim is to elevate Turkey to the ranks of contemporary civilizations" (Berkes, 1964). Turkish society perceives the process of modernization as a process of Europeanization, the adoption of European norms, attitudes, and standards of living (Mardin, 1991), and, therefore, Turkish people reject traditional (i.e., non-European) elements. It is within this context of modernization and Europeanization that Turkish women were granted certain rights, atypical for an Islamic country.

When in 1923, Turkey made its bid towards gaining acceptance as a European state in its own right (Berkes, 1964; Müftüler-Bac, 1997), one of the stumbling blocks on the way to modernization was the oppression of women in Turkey. As part and parcel of Turkey's modernization process embarked in 1923, Turkish women were emancipated and Turkey became the only Islamic country that granted social, legal, and political rights to women early in the 20th century. A few lucky women who came from the highest socioeconomic backgrounds in Turkey were chosen as the leading "army." This small, privileged group was able to receive the same education as men and compete with them under the same conditions for jobs. Paradoxically, the presence of an emancipated small group of women does more harm to women in Turkey because it creates the illusion that Turkish women are not subject to oppression as in other Islamic countries. In addition, the recognition of social and political rights in Turkey well ahead of many Western countries, "perhaps preempted the emergence of a women's movement" (Arat, 1989, p. 33).

Despite many rights Turkish women acquired at least on paper, there still exist serious obstacles to Turkish women's liberation, and a vast majority of Turkish women lack the opportunities to enjoy their rights as granted by the Turkish legal system. A number of scholars 
claim that Turkish women are emancipated but unliberated (Arat, 1989, 1994; Kandiyoti, 1987; Tekeli, 1995). Therefore, it seems contradictory that despite modernization efforts and legal changes, Turkish women are still oppressed by the patriarchal system.

On the surface, there seems to be a dichotomy between two types of women in Turkish society: the open, Western, emancipated woman, and the closed, traditional, "unliberated" woman. A favorite sight for foreigners is the Turkish girl in a miniskirt walking side by side with her veiled sister. Whether the liberal, Western-oriented woman or her traditional, pious sister represents the majority of Turkish women is the question in many minds. This article claims that the divide among Turkish women is a reflection of the identity crisis or the cultural dilemma that Turkish society has been facing since the 19th century. This article proposes that the perception that Turkey is the only Islamic state where women are emancipated is an illusion. There is a small, elite group of educated, professional, Western-oriented women in Turkey, the existence of which contributes to the fallacy that Turkish women are not chained by discriminatory practices as in other Islamic countries, and that they are in a much better position than their Middle Eastern sisters. However, the seemingly bright picture-that Turkey as the most modern, democratic, secular Muslim state that also secures woman's rights-is misleading in many ways. In fact, I propose that this perception is more harmful than outright oppression because it shakes the ground for women's rights movements by suggesting that they are unnecessary.

Women are oppressed in all countries from the most modern to the most traditional, but to varying degrees and in varying intensities. They suffer from political, social, economic, and legal inequalities as well as equality of opportunities. This article does not claim that the problems Turkish women face are no longer an issue in the West, on the contrary, despite religious and cultural differences, Turkish women share with women at large similar patterns of oppression. In northwestern Europe, women seem to be doing comparatively better than Turkish women, however, many of the issues raised in this article are still very much at the core of women's liberation movements in the West. What sets the Turkish case apart is the Turkish aspiration to be accepted as a European country, and the way that the status of Turkish women is used towards that end. Thus, an illusion that Turkish women are emancipated is essential to fulfil that aspiration, and the projection of that image is found to be more important than their actual emancipation.

The status of women has been an issue of much controversy in the process of Turkish modernization. Whether to veil women or not, and under what conditions to integrate them into the public sphere, is one major axis around which modernization efforts have revolved. When in the 19th century, modernization efforts began in the Ottoman Empire, the predecessor of the Turkish Republic, two opposing camps emerged in Turkish society; the modernizing, secularizing, Western-oriented elite and the traditional, Islamist, and reactionary conservatives. Their struggle still continues in modern Turkey, impacting political and social developments (Arat, 1989; Arsel, 1987; Müftüler-Bac, 1997). The most visible line of demarcation between these two opposing camps is Turkish women. Interestingly, the status of women became one important criterion determining the extent and success of modernization and Westernization efforts. The emancipation of women became the barometer of Turkish modernization, to the extent that the reactionary groups of the anti-Western social strata have fought the war against Westernization on women's bodies and dress. Turkish women have suffered mostly from being "the focal point of intense debate among groups with conflicting political interests," but what most groups agreed on was "the necessary continuation of the patriarchal domination of men over women" (Tekeli, 1995, p. 10).

As part of the reform package enacted upon the establishment of the Turkish Republic, women were granted social and political rights, an analysis of which is provided in the next section. Turkish women's rights were granted and promoted by the Kemalist elite, mostly men; it was not achieved as a result of women's movements since, at the time, they were nearly nonexistent. Women's liberation movements gained momentum in the 1980s as educated, professional women began pushing for modifications in the legal system and dominant social norms. Thus, one explanation for the relative weakness of women's rights move- 
ments in modern Turkey is that under Kemalism, a number of changes were made. At first glance, Turkish legislation concerning gender roles seems egalitarian, especially for an Islamic country. In reality, Turkish legislation reflects conventional gender ideology where gender roles are constructed around "male breadwinner-female homemaker" roles (Duncan, 1996, p. 419). The utmost duty for Turkish women is to be good wives and mothers, basically because "the woman" is viewed as the mechanism for protecting the cultural boundaries that set the community apart from other societies (Bouhdiba, 1985; Moghadam, 1994). The fact that Turkey is a Muslim society increases the symbolic value of women as the differentiating element between West and non-West. For example, when women veil themselves, they emphasize the physical differences between men and women, and, by doing so, demarcate the boundary lines between Islam and secular Western modernity. In this manner, women become the guardians of tradition and collective identity. It is for this reason that Turkish women's subordinate position partly stems from their identity as the social and biological carrier of the community (Arat, 1989; Kagitçibasi, 1982; Kandiyoti, 1982).

\section{AGENTS OF OPPRESSION IN TURKEY}

What Turkish women share with their contemporaries in other societies is that women are the "second sex" (de Beauvoir, 1953), and they try to survive in a male constructed system (Arat, 1989, 1994; Cindoglu, 1997). The image of urban, middle-class, Turkish women is pretty similar to "Western standards" in their dress code, living standards, and political rights. There are two problems in this picture, first the proportion of Westernized Turkish women is pretty small, and second, all Turkish women are bound by the same gender roles dominant in Turkish culture. Turkish women face various forms of oppression and subordination in their daily lives; these can be categorized under tangible and intangible forms of oppression. The intangible ones include legal discrimination, economic inequality, and social inequality. The tangible ones comprise sexual harassment, assault, insult, battering, rape, virginity tests, torture, and murder at the most extreme. A preliminary list of the factors that comprise patriarchy in Turkey would include: the Mediterranean culture, Islam, and Kemalism-the official state ideology.

\section{The Mediterranean culture}

The Mediterranean culture is the machismo tradition that one can come across to varying degrees in all Eastern Mediterranean societies. In the Mediterranean region, it is claimed that women are subject to oppression and exploitation by all religious groups (Beck \& Keddie, 1978; Delaney, 1987; Mernissi, 1975; Tillion, 1966), and there seems to be a set of family laws common to the region that crosscuts national boundaries, with the possible exception of France and Northern Italy. The Mediterranean family structure is based on male superiority and female inferiority, ${ }^{1}$ which is reproduced by women themselves as mothers and mothers-in-law. For example, a recent study on sexuality in Turkey (Report on Sexuality in Turkey, 1996) revealed that the most conservative group among those interviewed are older (age group 50-59), married women with children of their own. This group vehemently opposed such notions as premarital sex, single women living on their own, extramarital affairs; $94 \%$ of those women opposed such practices. These results suggest the importance of women as transmitters and protectors of dominant social values and norms. The culturally defined modes of control in the Mediterranean region are deeply vested in traditions and social norms constraining female behavior. Male superiority is maintained through honor and shame codes and women's oppression is justified by society's rules of appropriate behavior. (Delaney, 1987; Peristiany, 1966, 1976). It is said that "The Mediterranean woman, frequently abused in spite of laws, sometimes sold, often beaten, forced to work and whose assassination may sometimes remain unpunished is the slave of our modern times" (Tillion, 1966, pp. 161-178). Male supremacy in the Mediterranean culture, endorsed by the asymmetrical power relations between men and women, in this manner acts as an agent of oppression over women in Turkey. The Mediterranean culture, therefore, is a basis of male dominance in Turkey, the pattern of which depends on the "virginity-fidelity-son-producing ethos" (Beck \& Keddie, 1978, p. 25). 
Islam

The second factor is Islam, the dominant religion in Turkey where the majority of the population, $99 \%$ is the official figure, is of Muslim faith. Islam divides the world into two, the public sphere that belongs to men, and the private sphere, the domain of domesticity that belongs to women. The two do not mix. Islam, with its strict rules of confining women to the private sphere, has traditionally incapacitated women's ability to receive education and to hold jobs, in short to exist in the public sphere. There are two competing views on how Islam views women; there are those who claim that equality between men and women is a basic principle in the Koran, the separate-but-equal argument (Hatemi, 1988). The proponents of this view claim that women are already liberated in Islam, therefore, there is no legitimate ground for women's rights movements. On the other hand, there are those who claim that Islam treats women as second class people (Arsel, 1987; Calislar, 1991). For example, male superiority is endorsed by Islamic law on family matters and inheritance. The fact that Koran is Allah's words legitimizes women's position as subordinate and inferior, since it would not be possible to challenge divine judgement. Islam provides the infrastructure for keeping women off the public sphere, equal or not; what is certain in Islam is that women are separated from (i.e., excluded from public sphere) men's realm.

According to Mernissi (1975), women were confined to their homes-excluded from the public sphere-because they have the potential power to upset the social order.

In Islam there is no belief in female inferiority. On the contrary, the whole system is based on the assumption that women are powerful and dangerous beings. All sexual institutions (polygamy, repudiation, sexual segregation, etc.) can be perceived as a strategy for containing their power. (Mernissi, 1975, p. 19)

A woman in the public sphere is a threat to social order because she carries with herself the danger of fitna-her ability to create chaos through her sexual attraction (Al-Hibri, 1982; Arsel, 1987; Göle, 1991; Ilyasoglu, 1994; Mernissi, 1975). For example, in the Ottoman Em- pire-from 1299 to its collapse in 1923-female behavior was determined and scrutinized through the triple coalition of state, religion, and family. The administration (i.e., the Palace), issued decrees stating the days of the week that women can go outside their homes and the proper form of clothing they should wear while outside. Such issues as the thickness of the veil covering the face, the proper length of the chaddur were decided by the state authority and broadcast through the decrees of the Sultan.

Covering oneself up is a sexual concept, women veil themselves because their faces, bodies, hair, and voice attract men; thus, Islam views woman only in terms of sexuality and not as part of humanity. Humanity is male and it has to be protected from the female. The importance to order of veiled women in Turkish society is evident in the clash between the modernizing and traditional tendencies.

Women's clothing, veils, slaves and polygamy were all themes that occupied a paradoxical place in the debate on the westernizing of Turkey at the end of the 19th century. These cultural particularities of Turkish life did not fit into the modernizing plans of the pro-Western elites who contemplated Turkey through the gaze of Europeans. But at the same time, it would seem that the Turkish or Ottoman identity lay almost entirely in these cultural traits, as if a great part of Turkish identity was tied to these traditional ways. (Seni, 1995, p. 25)

At the end of the 20th century, the debate in Turkey still continues over the extent to which women can reveal their bodies and participate in public life without upsetting public order. In the 1990s, as a result of the increasing strength of political Islam in Turkey, one observes a reversal to Islamic dress and to Islamic rules for gender roles. An interesting example of the relevance of the debate to modern Turkish life is the dispute in January 1998 as to whether women can pray along with men at funeral services or whether the presence of women in the crowd would jeopardize the integrity of men's prayers. ${ }^{2}$ The proponents of the Islamic tradition are adamant that women have no place among men in public prayers, and that the presence of women upsets the general order. It is for this reason that, even when properly 
veiled, women in modern Turkey are still physically separated among the pro-Islamic, traditional groups from men in all gatherings.

\section{Kemalism}

The third agent of oppression in Turkey, paradoxically, is Kemalist ideology. In contrast to Islamic premises, Kemalist ideology aims at integrating women into Turkish public life. When the new Turkish republic was founded in 1923 on the ashes of the Ottoman Empire, the founder, Mustafa Kemal Atatürk strove to create a modern state. The emancipation of women was found to be critical in this endeavor.

The first step toward emancipation was marked by changes in dress codes. The Kemalist reforms of dress eliminated the curse of sexuality from Turkish women by forbidding the use of veil and chaddur. Through the dress reforms of 1925, the Islamic way of dressing was abandoned in favor of Western attire. Second, the Civil Code of 1926 eliminated the Islamic rules for marriage even though it still depended upon male dominance for the survival of the family as a social institution. The new Civil Code forbade polygamy-under Islamic laws of marriage, a man is entitled to four wives and can divorce any one of the wives himself. The Civil Code introduced gender equality in marriage, divorce, and in matters of inheritance, and granted equal child custody rights for both parents. Third, in 1930, Turkish women were granted the right to vote in local elections and in 1934, the right to vote for and to be elected to public office in national elections, rather early even when compared to their European sisters. These reforms during the early years of the Turkish Republic brought legal equality for women, at least on paper. As a consequence, women became staunch allies of the Kemalist regime, which granted them rights and liberties. Women's rights became part of the process of modernization and secularization (Arat, 1989; Kandiyoti, 1987; Tekeli, 1995). During the early years of the Turkish Republic, "most of the feminists have become militant 'Kemalists' and for the prominent women of this generation 'feminism' and 'Kemalism' became synonyms" (Tekeli, 1986, p. 193).

One should note that even though Kemalism had highly improved women's lot in Turk- ish society, the integration of women into public sphere was possible only if women concealed their femininity and displayed modesty in their attire and behavior. The ideal woman is portrayed as pure, honorable, and unreachable, serving the higher cause of modernization in Turkey. In that manner, Turkish women are seen as self-sacrificing, sacred creatures whose integration into public sphere as teachers, nurses, and professionals does not threaten morality or order. The price for female freedom in this early republican era in Turkey was the suppression of female femininity, thus visibility. Islamic practice controls women's visibility-their potential to threaten public order-by separating private and public spheres and by veiling women. Kemalism, on the other hand, controls their visibility by developing a stereotype of a Turkish woman; modest in appearance, companion to her male in modernizing the country. In that aspect, Islam and Kemalism were similar in that both depended upon the notion that women constituted a threat to the social order. Islam dealt with that threat by confining women to their houses and Kemalism dealt with that threat by stripping women of their sexuality and by putting forth asexual stereotypes that typified the new Turkish woman.

\section{The Leftist Ideology}

The Leftist ideology, dominant in Turkish politics, especially among the modernizing forces in Turkish society, from 1965 to 1980 , is another ideology that tried to strip women of their sexuality. In this manner, the Leftist ideology treated the female question in Turkey in a similar manner to Kemalism and Islam. The Turkish Left took upon itself the liberation of all the Turkish people and it did not handle women as a separate category. The "female problem" was perceived to be one of the numerous ailments of the Turkish bourgeoisie or the capitalist development in Turkey. The Turkish Left consisted of the Republican People's Party, Communist Party, Turkish Workers Party, trade unions, as well as student organizations in various universities. Even though all these groups had varying levels of commitment to a "socialist revolution," they converged around the notion that feminism is a bourgeois phenomenon, blocking the way to societal salvation (Sirman, 1989; Taylor, 1983) 
During the 1970s, the Turkish Left focused on women's rights as part of a systemic social transformation. "The Turkish Left has traditionally ascribed the oppression of women to the socio-economic backwardness of a country said to be dominated by feudal relations" (Berktay, 1995, p. 251) Women were included in the Leftist movements as comrades and asexual beings, reminding one of the Islamic argument that women constitute a threat to the public order. It would be interesting to note that women working side-by-side with men are called baci-sister, thus eliminating the threat of sexuality. The Turkish Left has used this terminology extensively to "denote an unsexed, depersonalized kind of "woman comrade" (Berktay, 1995, p. 252). Tansu Ciller, the leader of the conservative, right wing True Path Party, who was the Prime Minister from June 1993 to January 1996 and Deputy Prime Minister until June 1997, refers to herself as baci when she appeals to the masses in an attempt to desexualize herself and be taken seriously as a politician.

To sum up, despite many improvements that the process of modernization and Kemalist reforms brought to women's rights in Turkey, the basics of male domination stayed intact. Left unacknowledged and untreated both by Kemalism and by the leftist ideology, the oppression of women in Turkey has not received the attention it had in Western societies. The patriarchal order persisted under a different cover. The legal equality granted by Kemalist reforms did not achieve the emancipation of women in Turkey. As Simone de Beauvoir (1953) pointed out: "Even when her rights are legally recognized in the abstract, long-standing custom prevents their full expression in the mores" (p. 10). This has been the situation in Turkey, even though Kemalist reforms took a drastic step toward women's emancipation.

In the 1990s, one witnesses a step backward toward Islamic practices. The popular support for pro-Islamic political party-Welfare/Virtue Party ${ }^{3}$ - has increased steadily since 1987 . In the 1987 local elections, RP received $18.4 \%$ of the votes and in the 1995 general elections, it received $21.7 \%$ of the national vote (MüftülerBac, 1998). Thus, Islam has become a major force to be reckoned with in Turkish society and politics. Its implications for the status of women is that militants of political Islam are demanding application of Islamic practices and Islamic law to women and family matters. The 1990s are witnessing the emergence of Islamic women as an important civil society movement. (Göle, 1991; Ilyasoglu, 1994) The paradox is that these women are in the public sphere but they live in the Islamic way. For example, there is a growing number of girls who are seeking education and employment but who wear the veil. These women, who mostly support the pro-Islamic Welfare/Virtue Party, follow the Islamic way of living but work for the Party. As Islam politicized in the 1980s, women came forth as militant activists, the veiled women became the symbol of activism for political Islam, while at the same time, they constituted the boundary line between Islamists and secular Westernists. ${ }^{4}$ One possible explanation for being outside yet veiling oneself is, of course, political. But, there is another side to the story. These women shield themselves from male harassment by their Islamic dress; their veil gives them space in the public sphere without being threatened by men. The veil in modern Turkey works as a protective shield against being labeled as fair game or a sexual being if and when women are outside their domestic space.

Thus, the veiled woman in Turkey in the 1990s could be considered to be a reaction to male dominance. It has been developed as a defense mechanism by those women who no longer want to be contained in their traditional realm, the house; but who feel threatened by men. For some, these women veil themselves because they are "hostile to the message of the feminist ideology" (Tekeli, 1986, p. 194). This may be true to a certain extent. However, the trend may be toward an opposite direction, that these "Islamic" women may be using the traditional dress as a weapon in order to secure themselves in the public sphere without being subject to male harassment. It seems, therefore, too simplistic to claim Islam the only culprit of women's oppression in Turkey.

One should note, however, that one common denominator for all social groups in Turkey, whether Islamists, Kemalists, or Leftists, is that a woman's value is determined by her sexual purity, which is addressed in the next section.

\section{NAMUS: SEXUAL PURITY}

In Turkey, woman's chastity remains the most important control mechanism over female 
freedom. Such social institutions as the family, the courts, and cultural traditions constitute the backbone of this control mechanism. The reflection of female chastity in modern Turkish society is namus, family honor that exists in varying degrees in other Mediterranean societies. Namus can be roughly translated to sexual purity. Kandiyoti reflects on sexual purity as another form of control over female behavior.

The corporate control over female sexuality becomes strikingly evident in the large number of different individuals who see themselves as immediately responsible for ensuring women's appropriate sexual conduct ... firmly imprinting the notion that her sexuality is not hers to give or withhold. (Kandiyoti, 1987, p. 325)

One aspect of sexual purity for women is that premarital and extramarital affairs are strictly forbidden. The basic difference between Turkish society and European societies is that, in Turkey, these activities are not personal but involve state authority. The state in Turkey is a party to women's sexual activities reflecting society's values vis-à-vis women's sexual purity. For example, married women caught in the act of infidelity receive jail sentences; single women caught with a married man may be subject to virginity tests to determine whether sexual intercourse has occurred; girls under state control, such as at state schools, orphanages, and mental hospitals, may be required to undergo virginity tests. For example, a former Minister of Health, Yildirim Aktuna, ordered regular monthly virginity tests for female patients while he was in charge of the Istanbul Bakirkoy Mental Hospital (Cindoglu, 1997, p. 257). These are all attempts by the state to control female sexuality.

Women's sexual behavior is a measure of both the society's and the state's dominant values in Turkey. A family's/men's honor is at stake when one of the women of the family is behaving or is reputed to be behaving in a nonvirtuous manner. Educating females, allowing them to walk on the streets, letting the girl choose her own spouse may all have the potential to threaten namus. In different social classes, 'namus' would be jeopardized by different misdemeanors. In middle class, it is only sexual liaisons that are not tolerated, in lower middle class, going to the grocery store alone is unacceptable. What is common to all classes is that the aim is strict control over female behavior. Even rumors are enough to besmirch the family honor. Namus can only be cleansedbecause it has been dirtied by the woman-by blood; so the woman has to be killed by one of the male members of the family. Namus murders are commonplace in Turkey, especially in groups of lower socioeconomic status. They are quite separate and distinct from crimes of passion. A striking example of such a "cleansing process" took place in Southeast Turkey in April 1996 when a 13-year-old girl ran from home and her 14-year-old cousin was ordered by the family to cleanse the family honor by killing her. In court, the judge sentenced the murderer cousin to $21 / 2$ years in prison because of the traditions of the region where the incident took place. 5

Thus, the most important aspect of sexual purity for women is virginity and chastity. That is partly because of their value as reproductive agents. The image of God as Father in monotheistic religions is sustained in the patriarchal and patrilineal social system, which both praises and preserves male dominance. A woman may claim a place in the social order only through her reproductive capacities. Women's virginity and chastity are the only guarantees that men can claim fatherhood; the patriarchal system controls female promiscuity in order to secure fatherhood. Judeo-Christian and Islamic premises legitimized male control of female sexuality for this purpose of legitimate birth.

The modern legal structure in Turkey is based upon the same concern: the control of female sexuality. A promiscuous woman is a danger to the social order created under Islam, but man's promiscuity is not controlled, it is even encouraged. The importance of female chastity in Turkish social order is best illustrated by Serif Mardin (1991), who claims that from the 17th century onward, female chastity/ morality as epitomized by female clothing and behavior has been used by religious reactionaries and conservatives as basis for urban rebellion. Din elden gidiyor-We are losing our religion - has been a favorite protest by the religious conservative reactionaries in order to express their discontent and opposition to the modernization efforts. The most visible proof for the process leading to infidelity was, of course, women's morality as measured by their clothing and behavior. The battleground of 
modernization was women's bodies and the most visible form of control over women's bodies is their virginity.

The most recent debate over women in Turkey is whether girls are to be subjected to virginity tests by the state. Virginity tests and controls of young girls are generally conducted on girls suspected of illicit behavior or on brides who do not bleed on their first night. The importance of virginity lies in its capacity to determine the woman's value in the marriage market and, therefore, her status in society. In December 1997, a new law was passed regarding virginity tests, stating that a girl may refuse to have such a check; but one should note that given the social value of virginity, a girl refusing to be checked would be automatically declaring herself a nonvirgin. "Being a virgin bride signifies a woman's purity and her loyalty to her family. In a sense, the virginity of the bride is an asset for both her family and the groom's family" (Cindoglu, 1997, p. 253). According to one study conducted by the Istanbul Social Research Foundation, more than $70 \%$ of men interviewed still regard virginity as an absolute condition in their brides (Report on Sexuality in Turkey, 1996, p. 37).

Female virginity is definitely not a personal choice, it involves society-a nonvirgin is faced with social alienation and marginalization. What is particular to Turkey is that it also involves the state. The Minister responsible for Women's Affairs, Ms. Isilay Saygin, in an interview to a Turkish daily newspaper (Yeni Yüzyil, 1998), stated that the Turkish state is responsible for girls' virginity and, therefore, virginity tests should be continued. ${ }^{6}$ She based her arguments on the supremacy of the social values and protection of the family reflecting the general attitude of Turkish society regarding virginity. These perceptions, deeply embedded into the collective memory of the Turkish society, reflect the dominant view of women as the social and biological carrier of the community. "Because of their reproductive capacity, women are seen as the transmitters of group values and traditions and as agents of socialization of the young" (Moghadam, 1994, p. 18). Their sexual purity, therefore, is essential for the survival of society's norms and values.

It is, therefore not a major surprise to find that most of the violence directed against women stem from namus-sexual purity concerns. Accordingly, a groom who does not find his bride a virgin on their first night may kill the bride, but still escape social alienation for his act. The fact that most virgins do not necessarily bleed on their first intercourse is mostly overlooked. The woman who does not bleed on her first night is either shot or sent back to her father's house as damaged goods. The extended media coverage of murder of women on account of honor seems to suggest that it is a common problem, especially in less-developed regions in Turkey. However, a society that cannot secure its women's survival cannot secure its women's welfare either.

If the woman escapes violence on her first night, there is no guarantee that life shall continue blissfully. There is violence directed against women, both inside their homes and on the streets. Wife battering is not uncommona recent report indicates up to $30 \%$ of all women in Turkey are regularly beaten by their husbands (Report on Domestic Violence, 1995). A common Turkish saying legitimizes the act by claiming that "Husbands both love and beat their wives."

As for single women, their sexuality poses a serious threat to social order. Even though a rank of professional women coexists with men in the public sphere, men still dominate over the "liberated" woman in terms of her personal life. For example, a single woman living on her own is dangerous to the community in which she is living, especially in middle-class neighborhoods. The reason is basically that she is not abiding the rules set by the maledominant system, which requires that she be married. An unmarried, independent woman living on her own is regarded as an anomaly. Thus, even the educated male has a tendency to view an unmarried, therefore, masterless woman, as fair game. Ayse Saktanber (1995) asserts that this tendency reflects the division of Turkish women into two categories; "those almost totally devoid of sexuality" (i.e., the family woman), and "those that are nothing but sexuality" (Saktanber, 1995, p. 155). This categorization reminds one of the mother/ whore dichotomy in the West. An event that took place in Istanbul in May 1998 illustrates this tendency to view single women as fair game; in a middle-class neighborhood of Istanbul, three models/actresses who lived together were attacked and gang raped in their own house by seven men. The media coverage reflected the society's biases that the women 
rather than the aggressors were guilty, because of their professions and lifestyles. ${ }^{7}$

In short, woman's value in the Turkish society is measured through her sexual purity, which is controlled by customs, mores, norms, and laws. The interplay of Mediterranean culture and Islamist ideology is the determining factor for measuring women with respect to their sexual propriety.

\section{TURKISH WOMEN IN STRUGGLE}

To recall the dichotomy of Turkish women mentioned above, the modern woman and the traditional woman, it seems that the common denominator for all Turkish women is the various forms of oppression they face. Rural and urban women face different problems, as do women from the urban middle classes and lower middle classes, but they are all subject to the rules of patriarchy. The patriarchal system survives by feeding on the continuity of male dominance, which is achieved by oppressing the female population. The most visible woman, the educated, middle-class, working woman, is as close as the Turkish woman gets to emancipation. The proportion of this type of woman to the whole population of women in Turkey is pretty small; $87.36 \%$ of all women in Turkey are not employed (Report on Domestic Violence, 1995, pp. 84-85), on the other hand, roughly $30 \%$ of all university professors, medical doctors, and lawyers are women; so those who are employed are mostly working in professional jobs. In the business sector, the proportions are much lower; for every 100 men at the executive level, there are 3 women. ${ }^{8}$ Economic equality is achieved by this small, privileged group, but they are still bound by the rules of the society in which they are condemned to live as proper women. What the Kemalist reforms have achieved is the integration of some women into the male-dominated system; what needs to be done-if equality is to be achieved-is transform the system itself, which is the ultimate aim of women's movements in Turkey.

A feminist movement flourished in the post-1980 period and became one of the most important social movements, helping to define civil society in Turkey. A student of Turkish politics would be quick to point out that 1980 is the year when the military took over civilian politics, which resulted in massive political re- pression. The women's liberation movement found fertile ground in that period. In 1983, abortion was legalized in Turkey with the Abortion Act. In 1987, a massive campaign against wife-battering began and a number of women shelters were opened. Women also began a campaign against sexual harassment on the streets or in public places. In 1990, a Women's Library and Information Center was opened in Istanbul for the purpose of disseminating information on women. In 1991, a Ministry of Women's Affairs was established. Women's Day celebrations on March 8 have attracted media and public attention.

In addition, in the 1990s, women's movements are trying to eliminate the legal bases of inequality such as the Civil Code and the Penal Code. Though it is a major improvement over the Islamic law, the Civil Code of 1926 still falls short of gender role egalitarianism. For example, Article 152 of the Code dictates that the Head of the Family is the man, Article 153 states that upon marriage woman has to carry her husband's last name. (A minor revision in May 1997 allows women to keep their maiden name along with their husbands'). Furthermore, the Civil Code states that the Head of the family is the father (Article 154), thus overlooking all the families in which the head can be a single mother; for example, divorced or widowed mothers with children. These articles are what women's movements aim to modify through legal amendments.

It is not only the Civil Code that perpetuates ties of subordination in Turkey. The Penal Code also discriminates against women. It is expected that women are the first target of violence in all societies, but laws protect women against such practices by punishing the culpable. In Turkey, a man who rapes a prostitute may be entitled to a reduction in his sentence, and a man who kills his sister, wife, mother, sister-in-law for her improper actions, is looked upon as the victim not the victimizer. Raping a married woman, therefore, not a virgin, has a lesser sentence than raping an unmarried woman in Turkey. The best illustration of gender-based legal inequality is Zina-extramarital sex. Zina, under the Civil Code, is a cause for divorce. However, under the Penal Code, married women accused of Zina are punished with jail sentences, whereas married men committing the same act of infidelity are not punished at all. Such patterns of oppression are so 
deeply embedded in the social and legal infrastructure that few question them or try to eliminate them. Fortunately, women's movements that campaign against these patterns of oppression are increasingly more active in the 1990s; two notable examples are, KADER, a new movement established in 1997 for the purpose of increasing women's participation at local and national politics; and Purple Roof, a women's movement organization that aims at eliminating violence directed against women in domestic and public sphere. There are also organized women's movements against domestic violence, against legal inequalities noted above. These feminist movements attract extended media coverage and generate hostility by the conservative circles.

A good method of keeping women down is to exclude them from education. In rural areas and in the lower middle-class neighborhoods in the cities, families are reluctant to send their daughters to school, even though it is compulsory. The Republican People's Party conducted a survey on women's education and the findings indicated that 8 million Turkish women, one third of the female population, do not know how to read and write (Yeni Yüzyil, 1997a) A recent study by UNICEF revealed that one out of every three school-aged girl does not receive any education in Turkey, and that $30 \%$ of all women in Turkey are illiterate (World Bank Development Report, 1995). The schooling of girls can be as low as $12 \%$ in certain regions in the rural areas. The reason for keeping girls out of the schooling process is that the interplay of the Mediterranean and Islamic tradition keeps girls at home learning domestic skills from their mothers. Illiteracy among women leads to worse outcomes, making it easier to subordinate these women who have no training and to keep them under their fathers, brothers,' or husbands' control.

While most girls are kept out of school, education materials are designed in such a manner that they indoctrinate the values and the rules of patriarchy. Thus, the socialization process of children into gender specific roles begins early in the family, but the schooling process is also one of the main elements in this socialization, like in most European countries. Books in primary and secondary schools portray gender roles in a specific manner and socialize the students into gender roles and responsibilities. For example, girls are almost always pictured with the mother, helping her cook, setting the table, or doing the laundry. The setting for the female child is always the domestic scene, while the boys are portrayed with their father, looking at the newspaper, watching television, helping with the chores outside, in short, engaged in "manly" activities. Journalist Nalan Kuloglu, investigated the gender roles in secondary school books on religion and morals, found that in almost all of them women are either ignored or treated in terms of their servility and subordination to men, mostly their husbands. The media and the daily newspapers in Turkey also contribute handsomely to this constant socialization. Television commercials and soap operas teach womanly behavior and condemn acts such as working outside the home as unfeminine and destructive to the happiness of family life. Newspapers provide women's section on separate pages titled "For Women," in which women are indoctrinated with helpful hints as how to make themselves better looking, sexually willing, good care takers, good cooks, etc.

The whole system-the family, schooling and the media-constantly sends one message to women. A woman's first duty is to marry as early as possible and continue her life as a docile, pleasant wife and a dedicated, sacrificing mother. This process of socialization into gender roles determines the power relations between the sexes.

The Foundation of Social Research Center's study on sexuality in Turkey found a clear correlation between education and gender roles (Report on Domestic Violence, 1995). $70 \%$ of uneducated women considered beating their daughters a viable way of disciplining their daughters, whereas only $3 \%$ of university graduate women thought so; $57 \%$ of the uneducated women considered that a woman's place was at home, and that the woman should not intervene in man's business-the saying goes in Turkish as "With flour in her hands, she is intervening in man's business"whereas no university graduate woman agreed with that. It also is more probable that women university graduates choose their spouses themselves, whereas the girls in rural areas and living in traditional settings have no chance of doing so.

It seems that women suffer from double oppression, they do not receive education and they are kept out of the labor market. Article 
159-revoked in 1991 - of the Turkish Civil Code stated that a woman required her husband's approval before she takes up employment. In a society where women ask their husbands' permission even to go out, ${ }^{9}$ let alone work outside the home, what the law dictates has less importance. A study conducted by the Turkish Prime Ministry, Family Research Institution revealed that $40 \%$ of all Turkish women do not work outside the home because of their husbands' objections (Report on Domestic Violence, 1995, pp. 120-121). Women from lower socioeconomic groups are faced with the inability to participate in labor market activities because of their lack of education and lack of skills. The social factors that keep women at home also serve an economic purpose. Turkey has high unemployment rates, therefore, the competition by women with men on the job market is highly undesirable. The labor force in Turkey is $47.4 \%$ of the population, with $69.9 \%$ male and $25.2 \%$ female; the unemployment ratio is $6.9 \%$. As for unemployment for educated young people, the ratio is $25.3 \%$ for males and $45.3 \%$ for females. Persons not in the labor force comprise $52.6 \%$, within this group housewives comprise $52.8 \%$, $63.3 \%$ of which live in urban areas. It seems, therefore, that females in urban areas (i.e., housewives mostly) are passive in the labor force (State Institute of Statistics, 1998). On the other hand, women in rural areas carry most of the burden for agricultural production; $67.2 \%$ of all women in Turkey are employed as "nonsalaried family workers," especially in agricultural production (Yeni Yüzyil, 1997a). According to the October 1997 Household Labour Force Survey conducted by the State Institute of Statistics (1998), 51\% of people employed in agriculture in Turkey were unpaid family workers and $71 \%$ of these were female (State Institute of Statistics, 1998). This means that women are carrying the highest burden in agricultural production, but do not receive any return for the value they create. To illustrate the obstacles women face in the labor market, one may mention that in the census of November 30, 1997, the State Statistics Institute collected information regarding employment and labor movements from the heads of the family-overlooking millions of married women who have jobs themselves, thus, indirectly, the Turkish state was declaring that the working women have no value to state statis- tics except as wives. Thus, the mechanisms of the labor market sustain gender inequality due to vertical and horizontal segregation.

\section{CONCLUSION}

To sum up, Turkish women are faced with oppression despite the Kemalist reforms of the 1920s. The agents of oppression over female freedom are the Mediterranean culture with its honor and shame codes, the Islamic tradition with its divine judgement on female behavior and the Kemalist ideology with its stereotype of an asexual, self-sacrificing Turkish woman.

Despite many reforms that granted Turkish women legal, social, and political rights in the 1920s, Turkish women are still far off from emancipation. It is this paradoxical character of Kemalist reforms that this article tries to emphasize. The process of Turkish modernization provided Turkish women rights, at least on paper, while it also created the illusion that Turkish women are emancipated. Consequently, the educated, professional women, produced by Kemalist reforms, were not organized under a women's rights movement until the 1980s, basically because they did not perceive the ongoing oppression of women in Turkey. It is this misperception that prevented the emergence of women's movements and helped sustain the contradiction of "liberated" women. Women suffer from lack of education, employment, and opportunities that are sustained by dominant social norms. Controlled in their sexuality, kept out of schools, discriminated in the labor market, Turkish women are still a long way from emancipation.

The "liberation" of Turkish women has been one of the best concealed lies in Turkey. In the 1980s and 1990s, a number of questions arose as to who Turkish women are. It is against this background that women's movements found fertile ground. One should note, however, that the women's question is only one aspect of the deeply buried identity crisis that Turkey is undergoing in the 1990s.

\section{ENDNOTES}

1. For a detailed analysis of the Mediterranean family structure, see Mediterranean Family Structure (Peristiany, 1976).

2. The issue became politicized in the second week of Jan- 
uary when the Islamists and secular modernizers polarized over the presence of women in public prayers sideby-side with men. Turkish daily newspapers, Yeni Yüzyil, Cumhuriyet, Hurriyet, and Zaman ran editorials on this issue for 2 days, January 15-16, 1998.

3. The pro-Islamic groups organized under the banner of the Welfare Party in 1987, which on the December 24, 1995 national elections came out as the first party from the ballot box. The rise of political Islam created a reactionary movement that consisted of a coalition between secularist civil servants, military, and the Leftist parties. The Welfare Party was outlawed in 1998, and its leader, Necmettin Erbakan, was asked to step down. The outlawed Welfare Party is reorganized under a new party named the Virtue Party since January 1998.

4. There is a similarity here between Turkey and other Islamic countries, such as Iran, in terms of increased strength of political Islam and women as its active militants (Keddie \& Hoglund, 1986; Moghissi, 1997; Ptuthi, 1995).

5. For an extended media report of the incident, see Turkish daily newspapers Milliyet (1996) and Zaman (1996). The way the incident was reported varied depending on the ideological orientation of the newspapers; for example, the secular-oriented newspapers reported the murder as horrendous, whereas Islamist newspapers, though they condemn the murder on religious grounds, view the incident as a result of social degeneration.

6. See the interview with Isilay Saygin published in the Turkish daily newspaper Yeni Yüzyil (1997b). In that interview, Ms. Saygin stated that virginity controls are within the state's authority and it is up to the state to DETER young girls from illicit sexual behavior. In that same interview, she also stated that Zina-extramarital sex-should be punished by prison sentences. Her statements caused a major uproar and certain women's groups demanded her resignation as a minister of women's affairs.

7. See the Turkish daily newspapers Hurriyet, Milliyet, Sabah, and Yeni Yüzyìl, May 7, 8, and 9.

8. "The Reality of Women in Turkey," reported by Dilek Gedik (1997).

9. Report on Domestic Violence (1995) findings show that $64 \%$ of all men claim that their wives have to ask for their permission for such acts as going out of the house, or wearing a short-sleeved dress.

\section{REFERENCES}

Al-Hibri, Aziza. (1982). Women and Islam. Oxford: Pergamon Press.

Arsel, Ilhan. (1987). Seriat ve Kadin. Istanbul: Orhanlar Press.

Arat, Yesim. (1989). The patriarchal paradox: Women politicians in Turkey. London and Toronto: Associated University Presses.

Arat, Yesim. (1994). Toward a democratic society: The women's movement in Turkey in the 1980s. Women's Studies International Forum, 17, 241-248.

Beck, Lois, \& Keddie, Nikki. (Eds.). (1978). Women in the Muslim world. Cambridge, MA: Harvard University Press.

Berkes, Niyazi. (1964). The development of secularism in Turkey. Montreal: McGill University Press.

Berktay, Fatmagül. (1995). Has anything changed in the Outlook of the Turkish Left on Woman? In Sirin Tekeli (Ed.), Women in modern Turkish society (pp. 250-262). London: Zed Books.
Bouhdiba, Abdelwahab. (1985). Sexuality in Islam. London: Routledge.

Calislar, Oral. (1991). Islam'da Kadin ve CinsellikWomen and Sexuality in Islam. Istanbul: Afa Press.

Cindoglu, Dilek. (1997). Virginity tests and artificial virginity in modern Turkish medicine. Women's Studies International Forum, 20, 253-261.

Cumhuriyet. (1998). Cumhuriyet, January 15-16.

de Beauvoir, Simone. (1953). The second sex. New York: Alfred A. Knopf.

Delaney, Carol. (1987). Seeds of honor, fields of shame. In David D. Gilmore (Ed.), Honor and shame and the unity of Mediterranean (pp. 335-48). Washington DC: American Antropological Association.

Duncan, Simon. (1996). Obstacles to a successful equal opportunities policy in the European union. The European Journal of Women's Studies, 3, 399-423.

Gedik, Dilek. (1997). The reality of women in Turkey. Yeni Yüzyil, December 22.

Göle, Nilüfer. (1991). Modern Mahrem-Forbidden modern. Istanbul: Metis.

Hatemi, Hüseyin. (1988). Kadinin Cikis Yolu-Women's way out. Ankara: Fecer Press.

Ilyasoglu, Aynur. (1994). Ortülü Kimlik: Veiled identity. Istanbul: Metis Press.

Kagitçibasi, Cigdem. (Ed.). (1982). Sex roles, family and community in Turkey. Bloomington, IN: Indiana University Press.

Kandiyoti, Deniz. (1982). Urban change and women's roles: An overview and evaluation. In Cigdem Kagitçibasi (Ed.), Sex roles, family and community in Turkey (pp. 101-120). Bloomington, IN: Indiana University Press.

Kandiyoti, Deniz. (1987). Emancipated but unliberated? Reflections on the Turkish case. Feminist Studies, 13, 317-338.

Keddie, Nikki R., \& Hooglund, Eric. (1986). The Iranian revolution and the Islamic republic. Syracuse, NY: Syracuse University Press.

Lewis, Bernard. (1961). The emergence of modern Turkey. London: Oxford University Press.

Mardin, Serif. (1991). Turk Modernlesmesi-Turkish Modernization. Istanbul: Iletisim.

Mernissi, Fatima. (1975). Beyond the veil: Male-female dynamics in Muslim society. London: Al Saqi Books.

Milliyet. (1996). Milliyet, April 7.

Moghadam, Valentine M. (Ed.). (1994). Identity politics and women: Cultural reassertions and feminisms in international perspective. Boulder, CO: Westview Press.

Moghissi, Haideh. (1997). Women and fundamentalism in Islam. In Ronit Lentin (Ed.), Gender and catastrophe (pp. 129-142). London: Zed Books.

Müftüler-Bac, Meltem. (1997). Turkey's relations with a changing Europe. Manchester: Manchester University Press.

Müftüler-Bac, Meltem. (1998). The never-ending story: Turkey and the European union. Middle Eastern Studies, 34, 240-258.

Peristiany, John. (Ed.). (1966). Honor and shame: The values of Mediterranean society. Chicago: University of Chicago Press.

Peristiany, John. (Ed.). (1976). Mediterranean family structure. Cambridge: Cambridge University Press.

Ptuthi, Raj. (1995). Islam and women. New Delhi: Anmol.

Report on domestic violence. (1995). Ankara: Turkish Prime Ministry, Family Research Institution.

Report on sexuality in Turkey. (1996). Istanbul: Istanbul Mulkiyeliler Foundation, Social Research Center.

Saktanber, Ayse. (1995). Women in the media in Turkey: 
The free, available woman or the good wife and selfless mother? In Sirin Tekeli (Ed.), Women in modern Turkish society (pp. 153-170). London: Zed Books.

Seni, Nora. (1995). Fashion and women's clothing in the satirical press of Istanbul at the end of the 19th century. In Sirin Tekeli (Ed.), Women in modern Turkish society (pp. 25-41). London: Zed Books.

Sirman, Nükhet. (1989). Feminism in Turkey: A short history. New Perspectives on Turkey, 3, 1-34.

State Institute of Statistics. (1998). October 1997 household labour force survey. Ankara: Author.

Taylor, Barbara. (1983). Eve and the Jerusalem-Socialism and feminism in 19th century. New York: Virgo Press.
Tekeli, Sirin. (Ed.). (1995). Women in modern Turkish society. London: Zed Books.

Tekeli, Sirin. (1986). The rise and change of the new women's movements. In Drude Dahlerup (Ed.), The new women's movement (pp. 179-200). London: Sage.

Tillion, Germaine. (1966). Le harem et les cousins, Paris: Seuil.

World Bank development report. (1995). Washington, DC: The World Bank.

Yeni Yüzyil. (1997a). Yeni Yüzyil, December 22.

Yeni Yüzyill. (1997b). Yeni Yüzyil, December 29.

Yeni Yüzyill. (1998). Yeni Yüzyil, January 15.

Zaman. (1996). Zaman, May 11. 